\title{
Conceptualizing Drama in the Second Language Classroom
}

\author{
Kathleen Rose McGovern
}

\begin{abstract}
Abstract: This paper reviews key literature published in English on drama and second language (L2) pedagogy. The author explores (a) the integral role drama has played in $20^{\text {th }}$ and $21^{\text {st }}$ century L2 teaching methodologies; (b) commonly cited approaches to integrating drama and L2 instruction; (c) uses of drama as a means of exploring culture and power relations within society, and; (d) major definitions and categorizations developed in the existing body of literature. To conclude, the argument is made that researchers must clearly explain and define their approaches to drama in L2 instruction and ground these approaches in relevant theories of second language learning.
\end{abstract}

\section{Conceptualizing Drama in the Second Language Classroom}

Since the 1990's, a vast and diverse body of literature has developed on the subject of drama in the second language (L2) classroom, which points to drama's usefulness in terms of L2 development and cultural and identity exploration as well as certain challenges associated with drama in the language classroom. Belliveau and Kim's (2013) literature review reveals that drama has been associated with many benefits to language learners, including: "fostering communication competence, embodied and engaging learning, contextuallysituated interaction, confidence and motivation in learning and using language and deeper engagement with literature" (n.p.). Schewe (2002: 73) points out that the process of making theater is "immediately related to our concerns as language teachers, because the ability to interact and to communicate in efficient ways is, after all, at the heart of language teaching/learning."

My own review of the literature follows the model of Hamann and Harklau (2010); that is, rather than conducting a one-time search of databases to locate literature containing certain search terms, I synthesize literature that has emerged as important over the course of my several-year investigation of drama in the L2 classroom. This includes reviewing four books on the subject 
(Byram and Fleming 1998; Bräuer 2002; Larsen-Freeman 2010; Winston \& Stinson 2014;) along with articles and dissertations identified in those books as seminal (e.g. Via 1972 ; Kao 1994); examining the scholarly work published in this journal, Scenario, devoted to drama and L2 education, particularly two literature reviews both calling for further research and indicating the potentials of drama in the L2 classroom (Belliveau \& Kim 2013; Schewe 2013); and discussing articles that have emerged over the course of my previous scholarly endeavors or that were recommended to me by scholars in the field. This review is also informed, along the lines of Smagorinsky's (2008) article, by my work over the past year as an editor for the Journal of Language and Literacy Education (JoLLE), for which I reviewed dozens of articles, several dealing with drama's place in language and literacy education. This review, then, is a written iteration of my endeavor to make sense of the many terms, approaches, and purposes of drama in the field of language education, and I share in the hope that it may help guide scholars interested in this rich topic, pushing us all to more clearly define what we mean when we write and speak of drama in L2 pedagogy. In writing about the use of "theater," "drama," or "performance" in L2 learning/teaching, researchers and practitioners might refer to such wildly different endeavors as the rehearsal and staging of a Shakespearian play for public performance, the writing of an original play by students, or the involvement of students in brief in-class improvisations or games, to name only a few. Surely, these practices are so different in nature as to result in completely different implications for teachers and learners. I argue that despite the attention given to drama/theater in L2 instruction by scholars, a lack of clarity in terminology and conceptual framing may create confusion in interpreting findings.

In the following four sections of this literature review, I examine (a) the integral role drama has played in $20^{\text {th }}$ and $21^{\text {st }}$ century L2 teaching methodologies; (b) commonly cited approaches to integrating drama and L2 instruction; (c) uses of drama as a means of exploring culture and power relations within society, and; (d) major definitions and categorizations developed in the existing body of literature. Drama's inherent versatility necessitates that researchers clearly define what exactly they mean when they use terms like "drama," "theater," or "performance" in L2 contexts. In addition to providing transparent definitions, researchers must also clearly situate themselves in a conceptual framework.

\section{Drama as Taken up by L2 Methodologies}

Drama has long been viewed as a useful tool for language teaching; several L2 teaching methodologies explicitly call for its use. From role-plays to script readings to gesture, methodologies of the mid- $20^{\text {th }}$ century to the current day have sought to capitalize on the benefits that drama offers in terms of communicative competence, lowering affective obstacles to language learning, increasing motivation and even aiding in memorization. Different methodologies have framed drama in relation to the theories they separately 
grew from. This results in the evocation of wildly contradictory views of the process of L2 learning and teaching to support similar practices of integrating drama into the L2 classroom.

The Audio Lingual approach with its behaviorist underpinnings has viewed the repetition inherent in the rehearsal of scripts as valuable to the language learning process (Larsen-Freeman 2010). Advocates of Communicative Language Teaching (CLT) have used Communicative Competence (Hymes 1971) to justify drama. CLT (as described in Larsen-Freeman 2010) calls for the use of role plays and other communicative games influenced by the theater in the belief that unscripted, spontaneous use of language would enhance students' communicative competence in the second- or foreign-language (Liu 2002; Dodson 2002; Via 1976; Kao 1994; Kao \& O’Neill 1998).

In contrast, viewing the development of a second language as akin to that of a first language, Total Physical Response (TPR) (Asher 1977) asks learners to act out words and phrases as a means of processing them with their whole bodies. This methodology focused on the embodied, kinesthetic nature of language learning. Total Physical Response Storytelling (TPRS) builds on TPR, and explicitly calls for teachers to use drama and storytelling with students. Ray and Seely (2015: 15) explain that TPRS is grounded in Krashen's (1981) notions of L2 acquisition, which aims to keep L2 instruction "fully comprehensible" and calls for "dramatizing stories with students often playing themselves"; in so doing, the students create dialogue including aspects of their personal lives because "we need to personalize our stories as much as possible for high student interest" (ibid. 28).

These methodologies each use theatrical terminology and advocate that teachers engage students in language learning through dramatic processes. Though they differ in their conceptualization of drama as an aid to Second Language Acquisition (SLA), they are united in that drama does not take center stage in the language learning process. As more holistic views of SLA mature, theater artists and language teachers have begun exploring approaches that view drama less as a supplemental part of a language class and more as a means of language teaching/learning in and of itself.

\section{Three Common Approaches to Drama and L2 Instruction}

A variety of approaches such as playwriting, devising, and even some unnamed approaches such as "creating performance-based identity texts" (Yaman Ntelioglou 2011: 595) have been explored in L2 research. Yet the following three approaches to drama in the L2 classroom emerge most frequently: Theatrical Performance, Process Drama, and Games and Improvisations. The first entails students rehearsing and performing a scripted play. The second requires students and teachers to take on roles in order to complete extended in-class improvisations, but not for performance. The third encompasses the broad array of approaches that call for theater games to be used in L2 contexts, such as the games of Spolin (1986) and Boal (1992). 
Theatrical Performance, in which learners study and perform a play, is characterized by O'Toole and O'Mara (2007), who discuss it in educational drama rather than specifically language education contexts, as grounded in the view that cultural knowledge of dramatic literature is "an essential pre-requisite for a fully educated adult" (205). Richard Via (1972) was one of the first to publish accounts advocating Theatrical Performance with L2 learners. As a Fulbright lecturer, Via (1972) travelled to Japan in 1966 to teach English as a Foreign Language (EFL) through theater. He led his class in staging a production of Our Town, then remained in Japan for five years to stage various American plays with his students. Via $(1972 ; 1976)$ advocated the use of theater as a means of introducing cultural concepts to L2 learners and believed it augmented their language skills because it necessitated the use of the target language for a "meaningful purpose" (Dodson 2002: 161). He also found it augmented students' speaking skills, self-confidence, and spontaneity while lowering inhibitions (Via 1972; 1976). Others who have researched this approach find that it increases the sophistication, confidence, and accuracy of communication (Schier 2002: 198), and that students are introduced to "the acquisition of theater terminology, working in a team, being involved in stage design and lighting, putting together a program, all in addition to studying the literature and historical background relevant to the work" (Lys et al. 2002: 223). Communicative competence and the acquisition of both a target language and target culture are commonly evoked in support of this approach.

Cheng and Winston (2011) present a different take on Theatrical Performance, modified in that the "performance" takes place in the classroom, rather than for outside spectators. Their study presents a theoretical argument for the inclusion of Shakespeare in the EFL curriculum (Cheng \& Winston 2011: 74) that is grounded in Cook's (2000) concept of play as an essential element of SLA, Bakhtin's (1981) notion of dialogism, Halliday's (1973) notion that language is socioculturally constructed, and Bourdieu's (1991) concept of cultural capital. Cheng and Winston (2011) study how the techniques that Cicely Berry (1993; 2008) of the Royal Shakespeare Company developed to train actors were used in an L2 classroom. The authors argue that having students perform Shakespeare can be "personally liberating... [because] In being freed, albeit temporarily, from the formalities of the classroom... there is evidence that these students achieved high levels of personal and emotional involvement" (Cheng \& Winston 2011: 74).

Even in this one approach, Theatrical Performance, it is clear that the conceptual lens applied by the teacher or researcher influences how drama activities unfold and how they are seen as enhancing L2 learning. In Via's (1972) approach, the focus was primarily on the acquisition of language and understanding of the target culture, while in Cheng and Winston's (2011) the focus was on the students in relation to societal power structures.

Process Drama consists of a completely different set of techniques from Theatrical Performance, and different conceptualizations are commonly used to frame it. The approach, pioneered by Heathcote in the 1960's, was originally 
termed “'drama-in-education' or 'educational drama"' and is "now referred to as 'process drama"' (O’Toole and O’Mara 2007: 210). O’Toole and O’Mara (ibid.) describe its key characteristics as: being improvisational in nature, involving no external audience, and calling for reflection on the part of the learners through discussion:

The drama is always improvised, creating the learning context on the spot in theclassroom, with the learners all involved as participants in making the drama and as characters within it - unfolding as it goes along, rarely complete, and never entirely pre-ordained. (ibid. 211)

On Process Drama in L2 contexts, To, Chan, Lam and Tsang (2011), describe it as

Concerned with the development of a 'dramatic world' co-created by the teachers and students. It emphasizes participants' active identification with and exploration of fictional roles and situations to make meaning and reflections (O'Neill \& Lambert 1982), and values presentation to an internal audience (the participants themselves) more than performances to an external audience (Bowell \& Heap 2001: 42).

Kao's (1994) doctoral thesis employed quantitative discourse analysis in conjunction with qualitative ethnographic analysis in a ground-breaking effort to gain empirical evidence supporting drama in L2 instruction. Kao and O'Neill (1998), regarded as the pioneers of Process Drama in L2 classroom contexts, call for teachers to involve students in long-term drama based projects resulting in student/teacher created work, thus engaging students in meaningful acts of communication to question their worlds and the role they occupy within it. This call has been taken up with enthusiasm; in Winston and Stinson's (2014) edited book, Drama Education and Second Language Learning, five out of the eight chapters focus on Process Drama.

Proponents of process drama in the L2 classroom have asserted that it facilitates natural interaction among students and teachers, allowing for a wider variety of registers to be explored (Kao et al. 2011: 32f), increases student engagement and participation (To et al. 2011), that it reduces affective barriers such as anxiety (Piazzoli 2011), and results in embodied, multi-modal interaction (Rothwell 2011). This approach has been well-defined, conceptualized, and explored in research, but because it calls for a particular approach to drama, the benefits and challenges associated with it may not extend to other dramatic forms.

The third approach, Games and Improvisations, has been integrated into the language classroom as an accompaniment to certain L2 Methodologies as well as part of larger dramatic processes such as Theatrical Performance or Process Drama. They are, consequently, present in many studies of drama in the L2 classroom and not explicitly tied to any one conceptual frame. Spolin (1986) and Boal (1992) developed the games most frequently cited in L2 literature. Spolin's (1986) games were originally created to help in the training of actors, 
but later adapted for the classroom. Boal's (1992) games were not intended to stand alone but rather to scaffold the larger practice of Theater of the Oppressed (Boal 1979). Nonetheless, his games are cited in studies with very different conceptualizations of drama and language learning from his original intent of sparking societal change. For instance, Paul (2015) encourages teachers to have a large repertoire of games (including those developed by Spolin and Boal) at their disposal, arguing that there is a parallel between the goals of the communicative approach and those of improvisational theater techniques. In contrast, Harman and Zhang (2015) argue for the use of Boalian techniques with L2 learners from a critical perspective (further discussed in the next section of this paper). In the varied justifications for using theater games and improvisation in the L2 classroom, it becomes clear that the conceptual frame underlying their use determines how the games unfold and what affect they might have on L2 learning.

The three approaches described above have attracted criticism as well as advocacy. Kao and O'Neil (1998: 3), criticize the ways in which some teachers use games and improvisations as "exercise-based, short-term, and teacher oriented." Dunn and Stinson (2011) point out that teacher artistry may determine whether or not Process Drama has a positive effect on the language classroom. Their study reveals that classrooms led by teachers with less experience in facilitating Process Drama saw fewer benefits for students' language learning. Considering Theatrical Performance with L2 learners, Fels and McGivern (2002: 20) note, "from a critical applied linguistics perspective, the scenarios typically chosen for drama-based foreign and second language learning promote the dominant culture, consciously or unconsciously reinforcing cultural behaviors, expectations, and relationships common to the culture of the language being taught." With this remark, Fels and McGivern draw attention to the potency of drama beyond its use as a language-teaching tool and the need for a careful examination of the reasoning underlying our praxis, the need for approaching the study and practice of drama in L2 contexts with a sound theoretical foundation.

\section{Drama, Identity and Power}

Several scholars have explored drama's potential to move beyond a simple focus on communicative competence to an analysis of how drama affects learner identities, cultural orientations, and issues of power (Bräuer 2002; Axtmam 2002; Wagner 2002; Harman \& Zhang 2015). Betty Jane Wagner (2002), a seminal scholar in the field of educational drama, asserts "no instructional strategy is any more powerful than drama-based education for creating situations in which students undergo an experience that has the potential of modifying them as persons" (ibid. 5). Axtmann (2002) likens this process to that of transculturation; in exploring and creating dramatic texts, students may explore their own cultures and identities rather than simply being exposed to the culture of the target language or rehearsing language in a 
behavioristic fashion. Fels and McGivern (2002) point out that not all dramatic approaches affect students in a positive light and invite teachers to adopt a critical stance by considering the following questions:

In the opening up of curriculum to the presence of our students, what learning will be realized within the interplay between the multiple world(s) of experience and identities embodied within each individual? What concerns, fears, challenges and questions will students entertain as they (re)language their world? What issues will they choose (if given a choice) to explore?...With what experiences, memories, stories will they gift us? How may we as teachers and learners engage in a meaningful dialogue that invites the sounding of all voices? (ibid. 21)

These questions invite researchers and teachers to approach drama from a critical sociocultural lens that views learners not as subjects required to master a target language or culture, but as complex beings able to participate actively in their own learning.

The theories that underlie this critical stance are those of identity and performance in language learning, a comprehensive discussion of which is beyond the scope of this review. However, two concepts are of central importance. The first is Norton's (2000) notion of second language identities, which views L2 learners as participating in the process of not only language learning but also constructing complex and constantly changing identities. Performativity as a linguistic construct is another important dimension, for it views the production of language itself as a sort of performance in which L2 learners in classroom settings "often adopt and reproduce normative understandings of language and learner identity" (Miller 2011: 89). These theories of identity and performativity have been taken up in several studies.

Yaman Ntelioglou (2011) studied drama in a mandatory High School classroom for immigrant adults in Canada. Her research is grounded in identity exploration and conceptualizes drama as way to create identity texts (Cummins 2006) with students in order to value the knowledge and experience learners bring to the classroom. In a similar study, Medina and Campano (2006) describe using "teatro" practices with $5^{\text {th }}$ grade linguistically diverse students in the U.S. Their study details the devising of a play that students performed to educate their teachers about their experiences with certain classroom management techniques. Medina and Campano (2006: 133) assert that drama "can open critical spaces within which students negotiate diverse perspectives and generate knowledge" and affords students a "safe space to fictionalize reality and enact more empowering individual and collective representations from which others might learn." Both studies are strongly grounded in the notion that theater can function as a means of exploring identity and empowerment in the L2 classroom.

Harman and Zhang's (2015) research plays with the intersections between linguistic, identity-based, and theatrical notions of performance and views drama as a means of disrupting the reproduction of cultural norms. Harman and Zhang's (2015) study includes several dramatic approaches including the 
processes of storytelling, improvisation in the tradition of Boal's (1979) forum theater, and group analysis. They make an argument for "Critical Performative Pedagogy (CPP)," as "a pedagogical resource used to embody and probe social equity issues such as the deficit construction of bilingual students" (Harman \& Zhang 2015: 69). Their description of performance to foster critical reflexivity with L2 speakers illustrates the nature of dramatic performance as a means of exploring the representation of self in relation to society. In the studies of Harman and Zhang (2015), Medina and Campano (2006), and Yaman Ntelioglou (2011), we see that the purposes for which we choose to use drama to teach language are equally important as the dramatic approaches we choose.

\section{Defining and Describing Drama in the L2 Classroom}

Previous literature does address the wide range of approaches to and reasons for merging drama and L2 instruction. A significant challenge in studying or defining drama in the L2 classroom is that drama, itself, is not a static entity. In addition to having its own evolutions, styles, and approaches, it has been paired with other disciplines to achieve a variety of goals throughout history. A few distinctions in approaches to drama in L2 learning include: (a) drama vs. theater, (b) process vs. product-based approaches, and (c) small scale vs. large scale forms.

One distinction that created confusion for me when I began to research drama and L2 instruction was that of "drama" as contrasted with "theater." The term "drama" has been used to describe activities in which students generate plays or scenes or participate in dramatic play whereas the term "theater" reflects drama's "manifestations in performance" (O’Toole \& O'Mara 2007). Despite the existence of such distinctions, books edited by Winston and Stinson (2014), Bräuer (2002), and Byram and Fleming (1998) all unite articles on what they term "drama" in the L2 classroom, but contain articles treating both "drama" and "theater," according to O'Toole \& O'Mara's (2007) distinction, thus rejecting this binary conceptualization of drama/theater. Furthermore, this binary excludes approaches that fall on a continuum between them, such as Cheng and Winston's (2011) study investigating theater games as preparation for students to perform Shakespearean texts for their classmates.

Another distinction differentiates between "product-based" and "processbased" approaches. A product-approach is envisioned as the selection, study and rehearsal of a text plus a final performance, often open to the public (Wagner 2002; Liu 2002; Moody 2002). A process-based approach, in contrast, focuses on the development of a dramatic piece through in-class improvisations and theater games; these student-generated creations may or may not be written down or performed for the public. Despite the appeal of this seemingly dual classification system, this view has been called into question. Moody (2002) and Shier (2002) argue that both approaches afford benefits to language students and may be integrated within a single project: 


\begin{abstract}
Theater, in particular, with its built-in commitment to both processes and product, provides an arena and model for learning that increases students' confidence to reach beyond individual limitations. At the same time, it promotes students' responsibility and desire to be actively engaged in their own learning process. (Shier 2002: 184).
\end{abstract}

The process versus product-based distinction, then, also creates a dichotomy that does not fully allow for the appreciation of the nuances available to the drama practitioner.

In Schewe's (2013) review of the literature, in addition to acquainting readers with the historical roots of drama in L2 instruction and providing an overview of previous research, he presents a model of the various approaches to drama in the L2 classroom. Schewe's (2013) model of "Small-Scale Forms and Large-Scale Forms" of performative language pedagogy presents a more nuanced view of drama than either of the previous dichotomous conceptualizations. For Schewe, Small-Scale forms include in-class improvisations that unfold in a shorter time frame (one class or one unit) and do not typically result in a staged performance (such as process drama); Large-Scale Forms include both script-based and devised theatre, which require more time. He asserts that Large-Scale Forms demand high motivation and dedication and can only be materialized in extra-curricular contexts (ibid.). Despite the potential of such distinctions in forms, I have not seen these terms adopted in literature, nor does Schewe's model call for an explicit link between the approaches he explains and theories of language learning or performance.

\title{
6 Conclusion
}

In my review of existing literature, I have identified two core issues to be addressed in future literature on drama in the L2 classroom. First, we must clearly and explicitly identify what dramatic approaches are being used; second, we must identify the theoretical or conceptual frame used to justify it. Some articles advocate the importance of a strong theoretical argument for drama in the L2 classroom (such as Eun and Hye-Soon's (2009) discussion of drama from a Vygotskian (1978) perspective). Others advocate specific dramatic techniques, such as Paul's (2015) advocacy for theater games in the L2 classroom. It is necessary, as we proceed, that researchers provide both halves of the puzzle - the theory and the practice. Scholars have already taken great strides towards defining and theorizing drama in educational contexts (e.g. O'Toole \& Mara 2007). Schewe's (2013) article, discussed in the previous section, moves us towards doing so in L2 contexts. It is imperative to recognize that drama is not a uniform entity; therefore, we cannot claim that all forms of drama in the L2 classroom result in the same benefits or challenges. Like all research, the study of drama in L2 contexts is affected by the positioning of the researcher (Miles \& Huberman 1994). In order for research to be meaningful to those consuming it, it is the researchers' responsibility to name the dramatic 
practices they are analyzing, define those practices, and justify them in relation to theories that align with their purpose. Much of the literature on drama in L2 acquisition uses sweeping terms that imply all forms of drama have similar purposes or outcomes, but this is demonstrably not the case. To a certain extent, a lack of definition and conceptual frame usurps the meaning from the practice and research of drama in the L2 classroom.

If, as Fels and McGivern (2002) assert, not all dramatic approaches are useful to second language learners and some are harmful, then a closer examination of what we mean when we say we are using drama is of the utmost importance. Our advocacy of drama in the L2 classroom must be accompanied by the question: "why are we using drama?" At the least, we must adopt dramatic approaches that are grounded in theoretically sound linguistic approaches to language teaching. At most, we may open up gateways in which drama becomes a medium for individual and societal change.

\section{Bibliography}

Asher, James (1977): Learning another language through actions: The complete teacher's guide book. Los Gatos, CA: Sky Oak Productions

Axtmann, Ann (2002): Transcultural performance in classroom learning. In: Bräuer, Gerd (ed.): Body and language: Intercultural learning through drama. Westport, CT: Ablex, 37-50

Bakhtin, Mikhail (1981): The dialogic imagination: Four essays. Austin, TX: University of Texas Press

Belliveau, George \& Kim, Won (2013): Drama in L2 learning: A research synthesis. In: Scenario VII/2, 7-27

Berry, Cicely (2008): From word to play: A handbook for directors. London: Oberon Books

Berry, Cicely (1993): The actor and the text. London: Virgin Books

Boal, Augusto (1992): Games for actors and non-actors (transl. A. Jackson). London: Routledge

Boal, Augusto (1979): Theater of the oppressed (transl. C. A. \& M. Leal McBride). New York, NY: Theater Communications Group (Original work published in 1974)

Bourdieu, Pierre (1991): Language and symbolic power. Oxford, UK: Polity

Bowell, Pamela \& Heap, Brian S. (2001): Planning process drama. London: David Fulton

Bräuer, Gerd (2002): Introduction. In: Bräuer, Gerd (ed.): Body and language: Intercultural learning through drama. Westport, CT: Ablex, iv-xvi

Byram, Michael \& Fleming, Michael (1998): Language learning in intercultural perspective: Approaches through drama and ethnography. New York, NY:

Cambridge University Press 
Cheng, Astrid Yi-Mei \& Winston, Joe (2011): Shakespeare as a second language: Playfulness, power and pedagogy in the ESL Classroom. In: Research in Drama Education. The Journal of Applied Theater and Performance 16/4, 541-556

Cummins, Jim (2006): Identity texts: The imaginative construction of self through multiliteracies pedagogy. In: Garcia, Ofelia; Skutnabb-Kangas, Tove \& Torres-Guzman, Maria E. (eds.): Imagining multilingual schools: Language in education and globalization. Clevedon, England: Multilingual Matters, 51-68

Dodson, Sarah (2002): The educational potential of drama for ESL. In: Bräuer, Gerd (ed.): Body and language: Intercultural learning through drama. Westport, CT: Ablex, 161-180

Eun, Barohny \& Hye-Soon, Lim (2009): A sociocultural view of language learning: The importance of meaning-based instruction. In: TESL Canada Journal/Revue TESL du Canada 27/1, 13-26

Fels, Lynn \& McGivern, Lynne (2002): Intercultural recognitions through performative inquiry. In: Bräuer, Gerd (ed.): Body and language: Intercultural learning through drama. Westport, CT: Ablex, 19-36

Halliday, Michael (1973): Explorations in the functions of language. London: Edward Arnold

Hamann, Edmund T. \& Harklau, Linda (2010): Education in the new Latino Diaspora. In: Murillo Jr, Enrique G.; Villenas, Sofia A.; Galvan, Ruth T.; Muñoz, Juan S.; Martínez, Corinne \& Machado-Casas, Margarita (eds): Handbook of latinos and education: Theory, research, and practice. New York \& London: Routledge, 157-169

Harman, Ruth \& Zhang, Xiaodong (2015): Performance, performativity and second language identities: How can we know the actor from the act? In: Linguistics and Education 32/A, 68-81

Hymes, Dell (1971): Competence and performance in linguistic theory. In: Huxley, Renira \& Ingram, Elisabeth (eds.): Language Acquisition: Models and Methods. London, UK: Academic Press

Kao, Shin-Mei (1994): Classroom interaction in a drama-oriented English conversation class of first-year college students in Taiwan: A teacher-researcher study. Unpublished doctoral dissertation. The Ohio State University, Columbus, Paper granted by National Science Council

Kao, Shin-Mei; Carkin, Gary \& Hsu, Liang-Fong (2011): Questioning techniques for promoting language learning with students of limited L2 oral proficiency in a drama-oriented language classroom. In: Research in Drama Education: The Journal of Applied Theater and Performance 16/4, 479-488

Kao, Shin-Mei \& O'Neil, Cecily (1998): Words into worlds: Learning a second language through process drama. Stamford, CT: Ablex

Krashen, Stephen (1981): Second language acquisition and second language learning. New York, NY: Pergamon Press 
Larsen-Freeman, Diane (2010): Techniques and principles in language teaching ( $2^{\text {nd }}$ ed.). Oxford, UK: Oxford University Press

Liu, Jun (2002): Process drama in second- and foreign-language classrooms. In: Bräuer, Gerd (ed.): Body and language: Intercultural learning through drama. Westport, CT: Ablex, 51-70

Lys, Franziska B.; Meuser, Denise; Paluch, John \& Zeller, Ingrid (2002): Performing Brecht: From theory to practice. In: Bräuer, Gerd (ed.): Body and language: Intercultural learning through drama. Westport, CT: Ablex, 207-232

Medina, Carmen L. \& Campano, Gerald (2006): Performing identities through drama and Teatro practices in Multilingual classrooms. In: Language Arts 83/4, 332-341

Miles, Matthew B. \& Huberman, A. Michael (1994): Qualitative data analysis ( $2^{\text {nd }}$ ed.). Thousand Oaks, CA: Sage Publications

Miller, Elizabeth R. (2011): Performativity theory and language learning: Sedimentating, appropriating, and constituting language and subjectivity. In: Linguistics and Education 23/1, 88-89

Moody, Douglas (2002): Undergoing a process and achieving a product: A contradictionin educational drama? In: Bräuer, Gerd (ed.): Body and language: Intercultural learning through drama. Westport, CT: Ablex, 135-160

Norton, Bonny (2000): Identity and language learning: Gender, ethnicity, and educational change. Harlow, UK: Longman

O’Neill, Cecily \& Lambert, Alan (1982): Drama structures: A practical handbook for teachers. Portsmouth, NH: Heinemann

O'Toole, John \& O'Mara, Jo (2007): Proteus, the giant at the door: Drama and theater in the curriculum. In: Bresler, Liona (ed.): International handbook of research in arts education. Dordrecht: Springer Netherlands, 203-218

Piazzoli, Erika (2011): Process drama: The use of affective space to reduce language anxiety in the additional language learning classroom. In: Research in Drama Education: The Journal of Applied Theater and Performance 16/4, 557-574

Paul, Abigail (2015): Incorporating theatre techniques in the language classroom. In: Scenario IX/ 2, 115-124

Ray, Blaine \& Seely, Contee (2015): Fluency through TPR Storytelling ( $7^{\text {th }}$ ed.). Berkeley, CA: Command Performance Language Institute

Rothwell, Julia (2011): Bodies and language: Process drama and intercultural language learning in a beginner language classroom. In: Research in Drama Education: The Journal of Applied theatre and Performance 16/4, 575-594

Schewe, Manfred (2013): Taking stock and looking ahead: Drama pedagogy as a gateway to a performative teaching and learning culture. In: Scenario $\mathrm{VII} / 1,5-23$ 
Schewe, Manfred (2002): Teaching foreign language literature: Tapping the students' bodily-kinesthetic intelligence. In: Bräuer, Gerd (ed.): Body and language: Intercultural learning through drama. Westport, CT: Ablex, 73-94

Shier, Janet Hegman (2002): The arts and the foreign-/second-language curriculum: An interdisciplinary approach to actively engage students in their own learning. In: Bräuer, Gerd (ed.): Body and language: Intercultural learning through drama. Westport, CT: Ablex, 183-206

Smagorinsky, Peter (2008): The method section as conceptual epicenter in constructing social science research reports. In: Sage Journals 25/3, 389-411

Spolin, Viola (1986): Theater games for the classroom: A teacher's handbook. Evanston, IL: Northwestern University Press

To, Lai-wa Dora; Chan, Yuk-lan Phoebe; Lam, Yin Krissy; Tsang, Shuk-kuen Yvonne (2011): Reflections on a primary school teacher professional development programme on learning English through Process Drama. In: Research in Drama Education: The Journal of Applied Theater and Performance 16/4, 517-539

Via, Richard. (1976): English in three acts. Honolulu, HI: The University Press of Hawaii

Via, Richard (1972): TESL and creative drama. In: TESL Reporter 5/2, 30-32

Vygotsky, Lev (1978): Mind in society (trans. M. Cole). Cambridge, MA: Harvard University Press

Wagner, Betty (2002): Understanding drama-based education. In: Bräuer, Gerd (ed.): Body and language: Intercultural learning through drama. Westport, CT: Ablex, 3-18

Winston, Joe \& Stinson, Madonna (eds.): (2014): Drama education and second language learning. New York, NY: Routledge

Yaman Ntelioglou, Burcu (2011): 'But why do I have to take this class?' The mandatory drama-ESL class and multiliteracies pedagogy. In: Research in Drama Education: The Journal of Applied Theater and Performance 16/4, 595-616 